\title{
ARTICULAR AND VASCULAR MANIFESTATIONS OF POLYMYALGIA RHEUMATICA*
}

\author{
BY \\ M. I. BRUK† \\ From the Devonshire Royal Hospital, Buxton, and the Rheumatism Research Centre, University of Manchester
}

Polymyalgia rheumatica is a syndrome encountered by no means infrequently in middle-aged and elderly people. It is characterized by pains and stiffness, which are more severe in the morning, are felt to be in the shoulder and hip girdle muscles and often in the spine and are usually associated with fatigue, malaise, anorexia, loss of weight, and depression. The most constant laboratory finding is a raised erythrocyte sedimentation rate (ESR), which is often elevated out of proportion to the demonstrable physical abnormalities.

\section{Historical Review}

This syndrome was first described by Bruce (1888), who reported five men, aged 60 to 74 years, who developed severe joint and muscle pains and stiffness associated with marked constitutional disturbance. He considered this to be a disease not previously described and named it "senile rheumatic gout".

Widespread interest in this disease, however, dates from the second world war; reports by Holst and Johansen (1945), Meulengracht (1945), Porsman (1951), Kersley (1951), Forestier and Certonciny (1953), Bagratuni (1953, 1956, 1957, 1963), Barber (1957), Gordon (1960), Boyle and Beatty (1961), Serre and Simon (1962, 1963), and Weissenbach, Nobillot, Freneaux, and Coste (1963) have clarified the clinical picture. Barber (1957) coined the name "polymyalgia rheumatica" by which it is generally known in Great Britain.

Whether polymyalgia rheumatica is a clinical entity with a specific aetiology, or a syndrome in the course of other diseases has not yet been established. There is no question that other diseases, such as rheumatoid arthritis, ankylosing spondylitis, psoriatic arthropathy, and polymyositis, may occasionally produce a clinically indistinguishable picture, the correct diagnosis only becoming apparent with the further evolution of the disease. The absence of any specific laboratory test or

\footnotetext{
*This paper presented at a meeting of the Heberden Society at Buxton on June 25, 1965, is based on part of an M.D. Thesis presented to the University of Cape Town in 1965. The discussion which took place at the Buxton meeting was published in the Annals (1965), 24, 582 .

† Present addsess: Karl Bremer Hospital, Cape Town.
}

radiological abnormalities in polymyalgia rheumatica increases the diagnostic difficulty.

Until the last few years, it had generally been considered that polymyalgia rheumatica was a disease sui generis, but much disagreement as to its basic nature persisted. The patients complain of pains in the muscles and this tends to direct attention to the muscles as the tissue primarily involved. No convincing histological abnormality of muscle has, however, been demonstrated.

In a proportion of patients, synovitis can be demonstrated in the central joints, particularly of the shoulder girdle, and it has been suggested that the syndrome may be a form of arthritis affecting predominantly the spine and limb girdles (Coomes and Sharp, 1961).

The reports from Scandinavia (Olhagen, 1963; Kogstad, 1963; Alestig and Barr, 1963, and Hamrin, Jonsson. and Landberg, 1964) of the demonstration of giant-cell arteritis in a high proportion of patients with polymyalgia rheumatica raises two further possibilities:

(1) That giant-cell arteritis must be added to the list of diseases which may simulate polymyalgia rheumatica

(2) That giant-cell arteritis and polymyalgia rheumatica are manifestations of a single disease.

The present study was undertaken in an attempt to determine the pathogenesis of the syndrome and to establish its relationship to giant-cell arteritis.

\section{Material}

19 men and 61 women with polymyalgia rheumatica were seen at the Rheumatism Research Centre, University of Manchester, the Withington Hospital, Manchester, and the Devonshire Royal Hospital, Buxton.

Eleven patients in whom the diagnosis had previously been made were recalled; the rest first attended between June, 1962, and December, 1964.

Four criteria were obligatory for inclusion in the series:

(1) A history of pain and stiffness affecting predominantly the shoulder and hip girdles and spine in middle-aged and elderly patients.

(2) A history of morning stiffness lasting at least 30 minutes. 
(3) The finding, on examination, of tenderness of the central joints, tendons, and ligaments.

(4) No clinical, radiological, or pathological evidence that the symptoms were due to any other defined inflammatory rheumatic disease.

A raised ESR was not necessary for inclusion.

\section{Method}

A detailed history was taken, particular attention being paid to the locomotor system and to symptoms suggestive of arterial involvement, including headache, visual disturbance, angina pectoris, and intermittent claudication.

A general physical examination was carried out with special attention to the locomotor and vascular systems. The cranial and accessible larger arteries were palpated and auscultation was carried out over the large vessels. The blood pressure was recorded in both arms and oscillometry recorded in the arms and legs when indicated.

In order to provide some background against which to compare the findings in this study, eighty hospital patients over the age of 50 with miscellaneous complaints were examined for palpable abnormalities of the cranial arteries and for vascular murmurs over the large vessels.

\section{Mode of Onset}

\section{Clinical Features}

The age at onset varied from 42 to 83 years (mean 61). The onset of locomotor symptoms was sudden in 35 patients and in these the symptoms rapidly became more severe, usually within one month. In the others, the onset of symptoms was more gradual, sometimes being preceded by a period of vague illhealth. At the onset pain and stiffness were usually felt around the shoulder girdle and less often around the hip girdle or spine. In the fully-developed syndrome, pain and stiffness were usually more widespread and were felt in the shoulder girdle, pelvic girdle spine, and knees, and occasionally in the elbows, wrists, fingers, and ankles. All had prolonged morning stiffness.

All but five of these eighty patients had a raised ESR of at least $20 \mathrm{~mm}$. 1st $\mathrm{hr}$ (Westergren) at some time during the course of the illness.

The sheep cell agglutination test (SCAT), which was performed repeatedly in 72 patients, was positive in two, a proportion that might be expected in a sample of the general population of similar age (Ball and Lawrence, 1961). No patients were excluded because of a positive SCAT.

\section{Articular Manifestations}

In this elderly population, many had evidence of degenerative joint and spinal disease. Painful limitation of shoulder girdle movement, usually bilateral, was a characteristic feature, being present in 76 per cent. of the patients. Painful limitation of spinal movement, usually associated with tenderness over the interspinous ligaments, was found in some region of the spine in 83 per cent., the cervical spine being affected in 64 per cent., the dorsal spine in 32 per cent., and the lumbar spine in 55 per cent.

Tenderness, often with synovial thickening especially of the sterno-clavicular joints, was common, as were multiple focal tender areas on the bones around the shoulder girdle, pelvis, and knees. The focal tender areas were usually at the sites of attachment of tendons and ligaments. Palpable synovial thickening or effusion in joints was demonstrable in two-thirds of the patients at some time during the course of the illness (Table I). In 40 per cent. of the

TABLE I

FREQUENCY OF SYNOVITIS AND FOCAL TENDER AREAS AROUND JOINTS

\begin{tabular}{|c|c|c|c|c|}
\hline \multirow[t]{2}{*}{ Joints } & \multicolumn{2}{|c|}{$\begin{array}{l}\text { Tenderness of or } \\
\text { around Joints }\end{array}$} & \multicolumn{2}{|c|}{$\begin{array}{c}\text { Synovial Thickening } \\
\text { and/or Effusion }\end{array}$} \\
\hline & No. & Per cent. & No. & Per cent. \\
\hline $\begin{array}{l}\text { Sterno-clavicular } \\
\text { Acromio-clavicular } \\
\text { Shoulder } \\
\text { Wrist } \\
\text { Pelvis or hip } \\
\text { Knee } \\
\text { Metacarpo- } \\
\text { phalangeal or } \\
\text { proximal- } \\
\text { interphalangeal } \\
\text { Temporo- } \\
\text { mandibular }\end{array}$ & $\begin{array}{l}55 \\
59 \\
56 \\
28 \\
55 \\
57\end{array}$ & $\begin{array}{l}69 \\
72 \\
70 \\
35 \\
69 \\
71\end{array}$ & $\begin{array}{r}32 \\
15 \\
6 \\
10 \\
0 \\
40\end{array}$ & $\begin{array}{r}40 \\
19 \\
8 \\
12 \\
0 \\
50\end{array}$ \\
\hline
\end{tabular}

patients synovial thickening was palpable in one or both sterno-clavicular joints. Effusions were present in the knees of half the patients, but in some these could have been due to osteo-arthrosis. The synovitis was characteristically transient, in some cases lasting only a few days, particularly in patients confined to bed. In seventeen patients, the affected sterno-clavicular joints later became unstable. In some, there was a tendency for the instability to diminish after several months.

Injection of local anaesthetic and hydrocortisone into the tender focal areas around joints was usually effective in relieving associated pain and tenderness, and the range of joint movement was often improved. The pain referred from the sterno-clavicular joint was felt to be in the muscles of the third to sixth cervical scleratomes, as might be anticipated from the fact that its nerve supply arises from these cervical roots (Johnston, 1938).

The greatest degree of shoulder girdle limitation was observed in those patients in whom the sternoclavicular joints were most tender, particularly at their capsular attachments. It was apparent that 
involvement of these joints was mainly responsible for the limitation of shoulder girdle movement, which is so characteristic a feature of polymyalgia rheumatica. Similarly, injection of local anaesthetic into tender interspinous ligaments resulted in relief of the spinal pain and often in an increased range of spinal movement.

\section{Histological Changes in Joints}

Biopsy of a sterno-clavicular joint was performed in five patients. In four, the synovium was markedly thickened and inflamed with numerous villous projections filling the joint space. On histological examination all showed chronic non-specific synovitis (Fig. 1) and inflammatory changes in the capsule, of varying degrees of activity. No rheumatoid factor was detected in the synovial and plasma cells when tested with F2 aggregated gamma globulin by immuno-fluorescent microscopy by $\mathrm{Dr}$. J. Ball.

\section{Radiological Changes in Joints}

Erosive changes in joints and/or sclerosis of the sacro-iliac joints were noted in seventeen patients (Table II). In twelve patients these changes were observed to develop during the course of the illness.

The joints most frequently affected were the pubis (Fig. 2, see p. 106), sacro-iliac (Fig. 3, see p. 107), and sterno-clavicular (Fig. 4, see p. 108).
TABLE II

JOINT EROSIONS AND/OR SCLEROSIS OF SACRO-ILIAC JOINTS

\begin{tabular}{l|c}
\hline \multicolumn{1}{c|}{ Joint } & No. of patients \\
\hline Wrist & 2 \\
Metacarpo-phalangeal or & 3 \\
proximal-interphalangeal & 5 \\
Sterno-clavicular & 3 \\
Acromio-clavicular & 8 \\
Sacro-iliac & 9 \\
Pubis & \\
\hline
\end{tabular}

Erosions of the sterno-clavicular joints were difficult to demonstrate on routine radiographs, but tomography done in three of the five patients with sterno-clavicular joint erosions confirmed their presence.

Three patients had lumbar instability with forward movement in flexion of the 3rd on the 4th lumbar vertebrae on routine lateral flexion and extension views of the lumbar spine. In one patient (Appendix-Case 5), the degree of instability increased during the illness.

\section{Muscle Involvement}

Muscle pain and tenderness were usually widespread, the muscle groups mainly affected being those of the shoulder and hip girdle and the paravertebral muscles. No evidence of muscle disease was found.

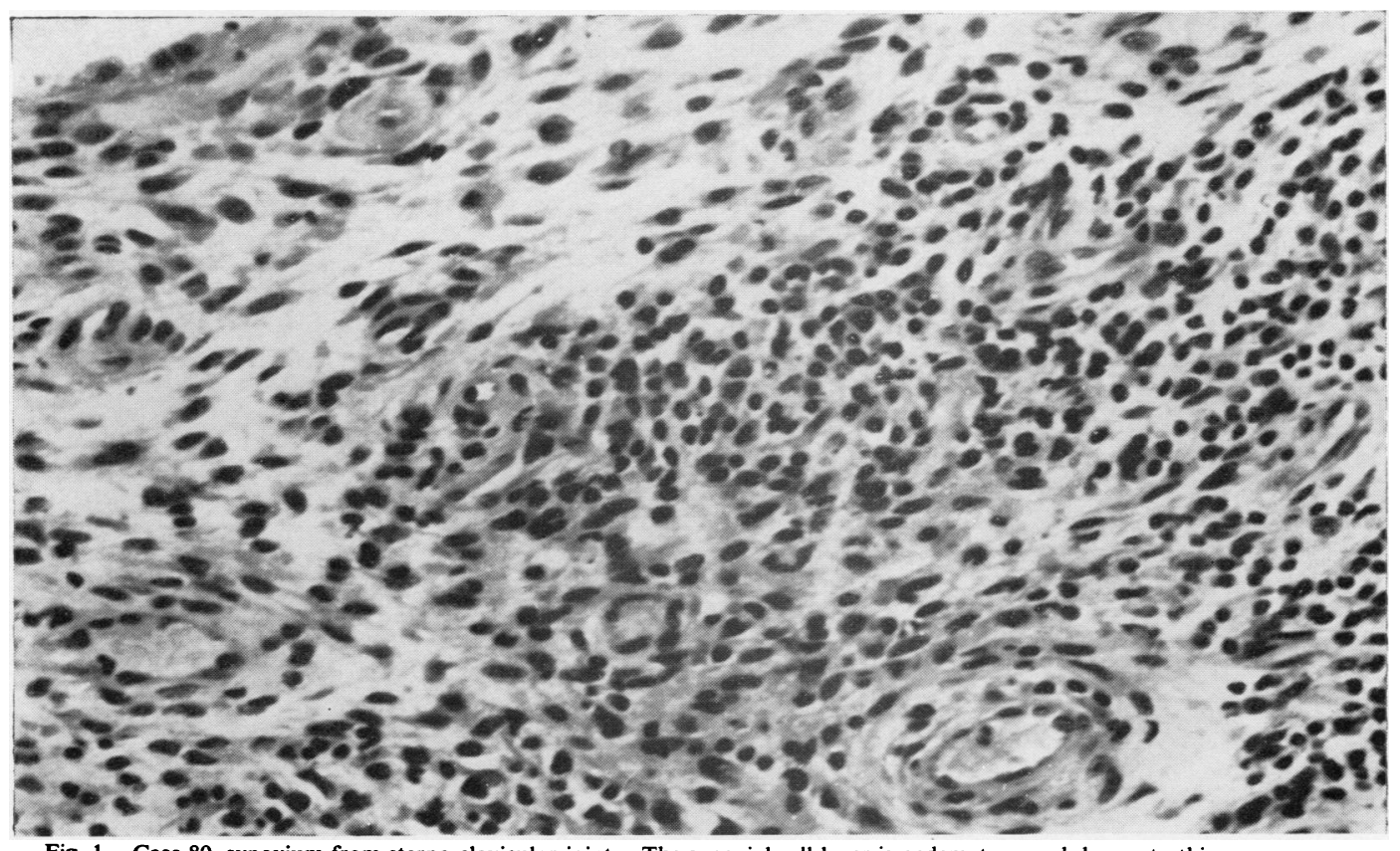

Fig. 1.-Case 80 synovium from sterno-clavicular joint. The synovial cell layer is oedematous and deeper to this are numerous lymphocytes and plasma cells. $\times \mathbf{4 0 0}$. 

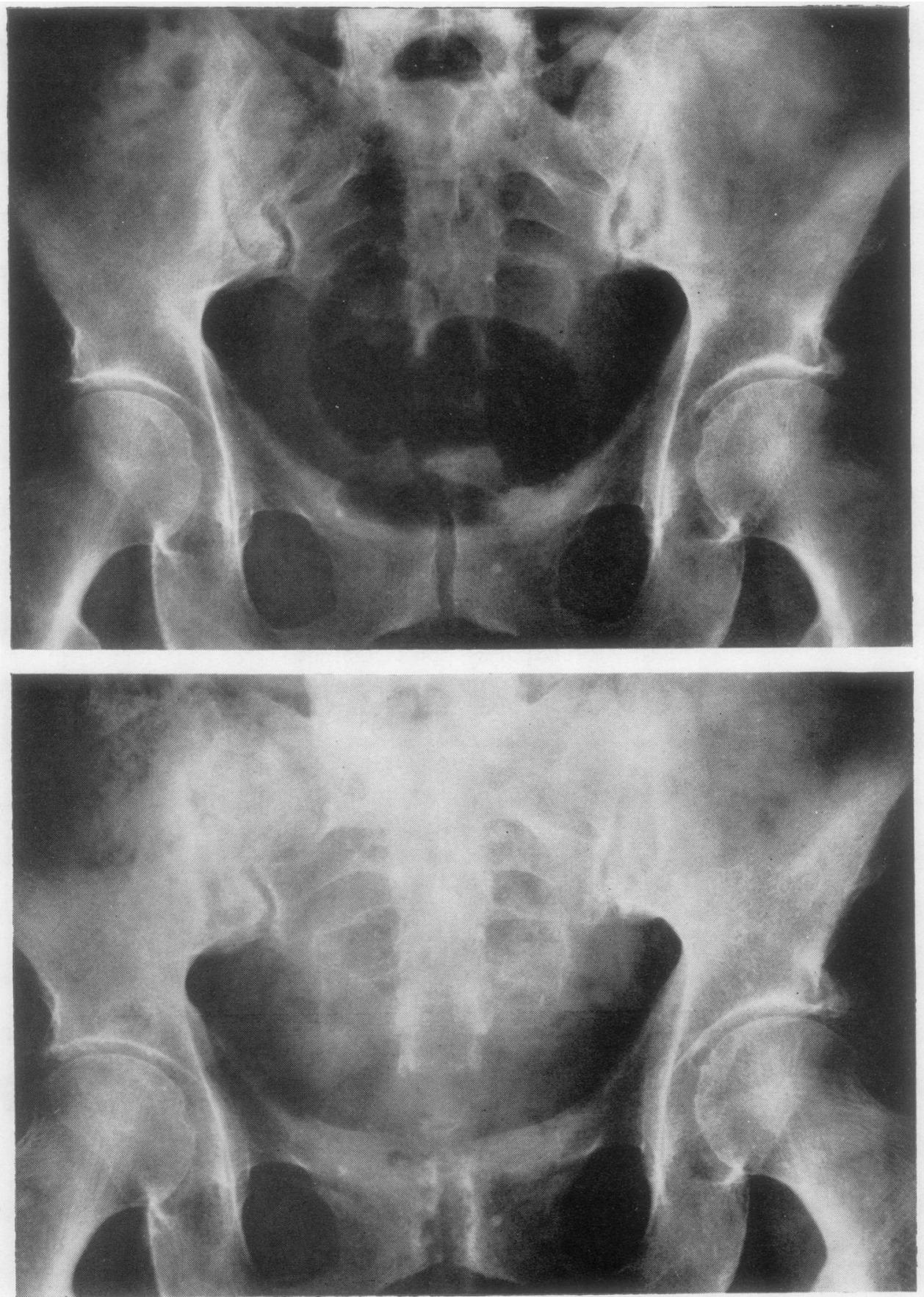

Fig. 2.-(a) Case 23, $x$ ray of pelvis (October, 1960). Both sacro-iliac joints are eroded and sclerosed. The pubis symphysis is normal. (b) (August, 1963). Marked erosion and sclerosis of pubis symphysis. 

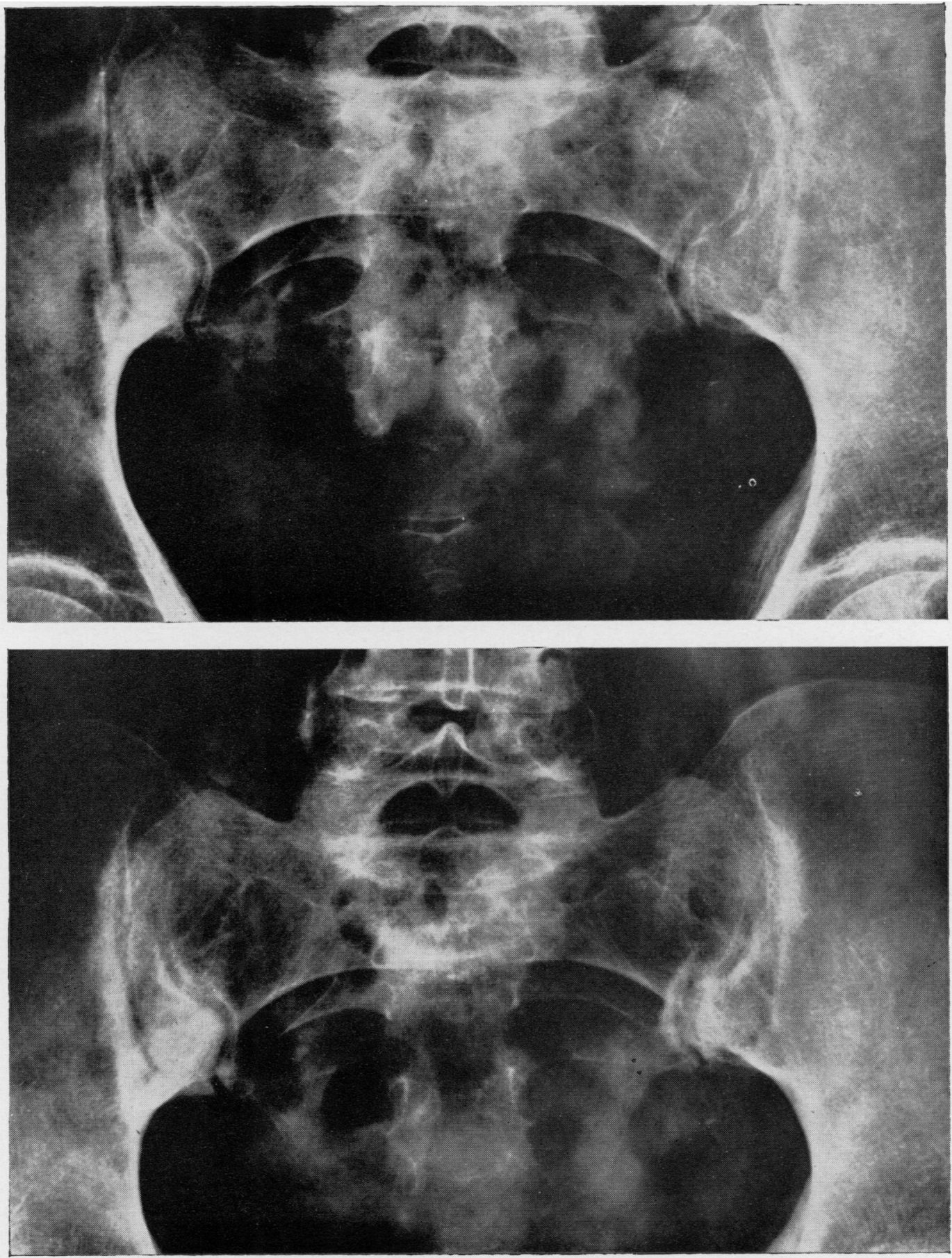

Fig. 3.-(a) Case 29, $x$ ray of pelvis (February, 1962) showing minimal sclerosis of right sacro-iliac joint. (b) (January, 1965). Increased sclerosis of right sacro-iliac joint and also sclerosis of left sacro-iliac joint. 


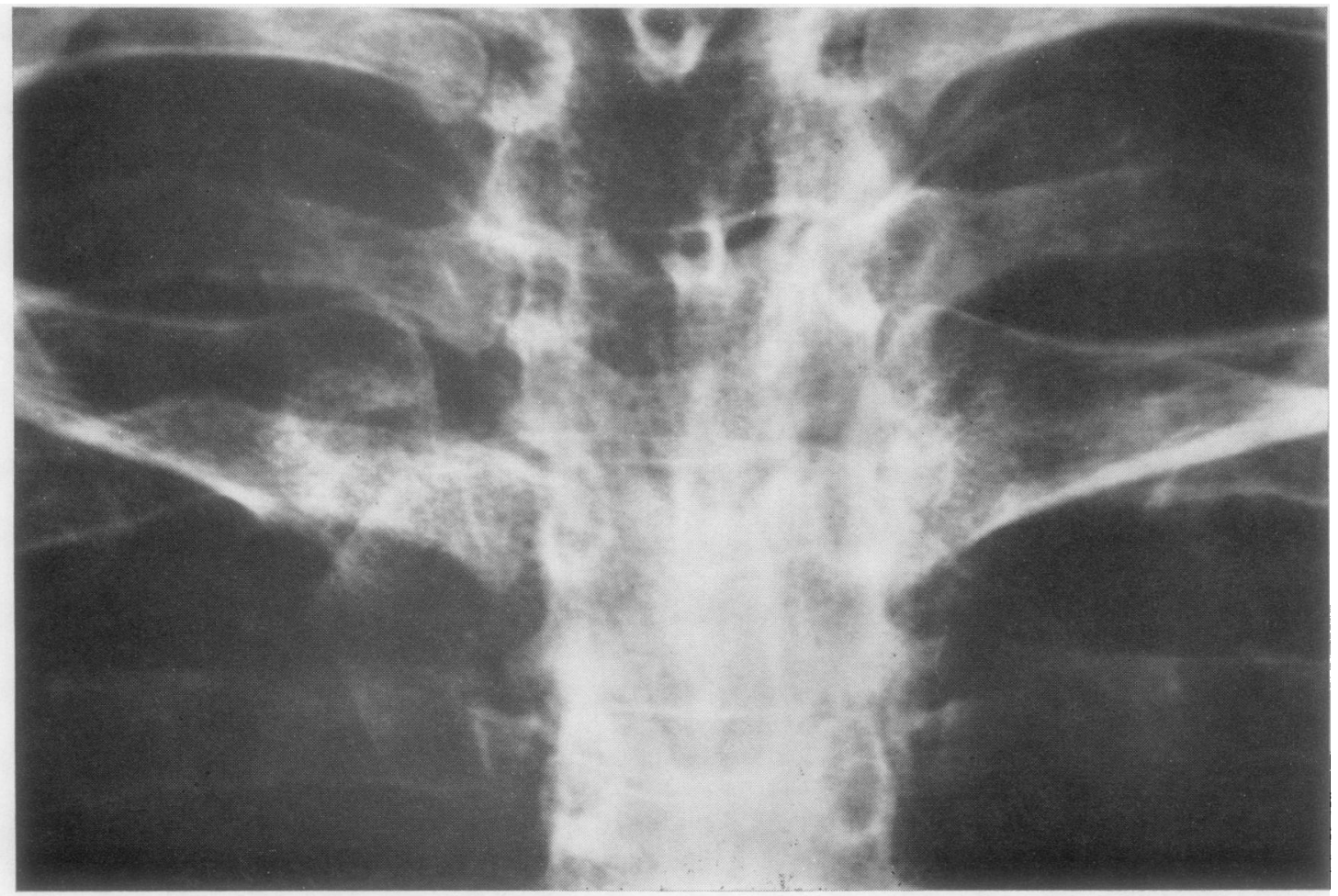

Fig. 4.-Case 28, $x$ ray of sterno-clavicular joint showing large erosion of medial aspect of right clavicle.

The muscle enzymes, serum creatine phosphokinase, serum aldolase, and serum transaminases in 21 patients were normal. Muscle biopsies in seventeen and electromyography in eighteen patients also showed no abnormality.

The muscle pain and tenderness were usually abolished by injection of local anaesthetic into the appropriate tender focal areas in central joints, tendons, and ligaments, and were therefore presumably due to referred deep pain and hyperalgesia arising from these structures.

Apparent muscle weakness was common, but normal power was restored after injections of local anaesthetic into the tender focal areas, usually at the origin or insertion of the muscle.

\section{Vascular Manifestations}

It is now generally recognized that giant-cell arteritis is a widespread arteritis of medium-sized and large vessels. Several patients had symptoms compatible with giant-cell arteritis (Table III).
TABLE III

SYMPTOMS COMPATIBLE WITH GIANT-CELL ARTERITIS

\begin{tabular}{|c|c|c|c|}
\hline \multirow{2}{*}{\multicolumn{2}{|c|}{$\frac{\text { Symptom }}{\text { Local Headache (severe) }}$}} & \multicolumn{2}{|c|}{ No. of Patients } \\
\hline & & 29 & (14) \\
\hline $\begin{array}{l}\text { Visual } \\
\text { Symptoms }\end{array}$ & $\begin{array}{l}\text { Transient unilateral blindness } \\
\text { Visual field defect } \\
\text { Transient blurring of vision } \\
\text { Visua! hallucinations } \\
\text { Diplopia } \\
\text { Ptosis } \\
\text { Photophobia }\end{array}$ & 16 & $\begin{array}{r}3 \\
3 \\
10 \\
1 \\
6 \\
1 \\
6\end{array}$ \\
\hline \multicolumn{2}{|c|}{$\begin{array}{l}\text { Anosmia } \\
\text { Angina Pectoris } \\
\text { Intermittent Claudication }\end{array}$} & \multicolumn{2}{|c|}{$\begin{array}{l}2 \\
5 \\
5\end{array}$} \\
\hline
\end{tabular}

29 patients had local headache most frequently in the temporal regions, this was severe in fourteen, but in several of the other fifteen patients it was disclosed only on specific inquiry, these patients being more concerned about their skeletal pains. The visual symptoms varied from transient blurring of vision to transient complete blindness and persistent visual field defects. Two patients lost their sense of smell, 
and five developed angina pectoris and five intermittent claudication during the active phase of the illness.

The time of appearance of symptoms or signs clearly attributable to arteritis was often difficult to determine, but, in almost half the patients, this appeared to occur within 6 months of the onset of polymyalgia rheumatica. In some, symptoms and/ or signs of arteritis only appeared after the locomotor symptoms had subsided and the ESR had returned to normal. In one woman (Appendix Case 5), who had initially had demonstrable synovitis of the sterno-clavicular joints and knees and a negative temporal artery biopsy, 35 months elapsed before she developed bitemporal headache with thickened tender temporal arteries and a positive biopsy.

Cranial Artery Biopsies were performed in 33 patients: two of them had a biopsy of an occipital artery, one had a biopsy of both temporal arteries, another two had a biopsy of a facial and a temporal artery, and in the remaining 28 patients a branch of a temporal artery was biopsied.

Fifteen patients had histological evidence of arteritis but in only six of these was the temporal artery considered to be clinically abnormal on palpatation at the time of biopsy. Tender thickening with reduced or absent pulsation of the cranial arteries was found to be diagnostic of giant-cell arteritis, and was recognized with the greatest ease in the temporal arteries.

Giant cells were present in nine of the fifteen positive biopsies. In the other six, no giant cells were seen in the vessel wall; four of these had had suppressive corticosteroid therapy and, in the remaining two, the changes were presumed to represent a healed arteritis. In one of these the vessel was almost completely replaced by scar tissue and in the other the lumen was markedly narrowed, and the vessel wall largely replaced by scar tissue.

Clinical Abnormalities of the Large Vessels.Arteritis of the large vessels is a well-recognized pathological feature of giant-cell arteritis, but is difficult to prove during life, particularly since atherosclerosis is so common in this age group. Abnormalities of large vessels were recorded, but no diagnostic significance was attached to them unless there was other evidence of arteritis.

Clinical abnormalities of the large vessels arose in several of these patients with polymyalgia rheumatica while they were under observation; these frequently appeared after an exacerbation of the constitutional illness, a marked rise in the ESR, and the appearance of increased alpha ${ }_{2}$ and/or gamma globulin fractions in the serum. In these patients, the vascular abnormalities were presumed to be due to an arteritis of the large vessels. These abnormalities arose in patients both with and without positive cranial artery biopsies, although in two with negative biopsies these had been performed several months before the abnormalities of the large vessels were noted.

Murmurs were audible over the large vessels in 22 of the eighty patients, in six a murmur was audible over only one artery, usually the subclavian, but in the other sixteen patients murmurs were audible over several vessels (Table VIII, see p. 110). Six of the eighty controls were also found to have soft vascular murmurs over one subcavian artery and another patient with severe Paget's disease of the skull had murmurs over both carotid arteries.

Tenderness over large vessels was found in these patients with polymyalgia rheumatica, but the significance of this was difficult to assess, since these tender vessels were often situated in areas of referred deep tenderness related to painful skeletal lesions in the vicinity.

\section{Classification of Patients}

These eighty patients were divided into three groups:

(1) Definite arteritis,

(2) Possible arteritis,

(3) No evidence of arteritis.

(1) 21 were considered to have definite arteritis. Of these, fifteen had positive cranial artery biopsies (Table IV). Another patient had tender temporal

TABLE IV

NUMBER OF PATIENTS WHO HAD CRANIAL ARTERY BIOPSIES, BY DEGREE OF ARTERITIS

\begin{tabular}{|c|c|c|c|c|c|c|c|}
\hline Arteritis & .. & .. & . & .. & Definite & Possible & None \\
\hline \multicolumn{2}{|c|}{ No. of Patients } & . & . & . & 21 & 17 & 42 \\
\hline $\begin{array}{c}\text { Cranial } \\
\text { Artery } \\
\text { Biopsy }\end{array}$ & \multicolumn{4}{|c|}{$\begin{array}{l}\text { No. of Biopsies } \\
\text { No. Positive }\end{array}$} & $\begin{array}{l}18 \\
15\end{array}$ & $\begin{array}{r}11 \\
0\end{array}$ & $\begin{array}{l}4 \\
0\end{array}$ \\
\hline
\end{tabular}

arteries with reduced pulsation, visual impairment due to occlusion of a branch of the central retinal artery, and widespread abnormalities of large vessels, but no artery was present in the tissue removed at biopsy. Two other patients had tender, thickened arteries, but no biopsy was performed. The three remaining patients (Appendix Case 28) developed clinical abnormalities of large vessels while under observation. 
(2) Seventeen patients were considered to be suffering from possible arteritis since they had suggestive symptoms and signs, but there was insufficient evidence to justify inclusion in Group 1.

(3) There was no evidence of arteritis in the remaining 42 patients. Those with murmurs of the large vessels when first seen who had no other clinical evidence of arteritis were classified in this group.

\section{Comparison of Patients with and without Arteritis}

\section{Locomotor System}

The abnormalities in the locomotor system of the eighty patients with polymyalgia rheumatica were similar in those with definite arteritis, possible arteritis, and no arteritis. Focal tenderness around joints and of the interspinous ligaments was equally common (Table V). The incidence of synovitis was

TABLE V

INCIDENCE OF FOCAL TENDERNESS AROUND JOINTS AND OF THE INTERSPINOUS LIGAMENTS, BY DEGREE OF ARTERITIS

\begin{tabular}{|c|c|c|c|c|c|c|c|}
\hline Arteritis $\ldots$ & .. & . & . & . & Definite & Possible & None \\
\hline No. of Patients & $\quad \ldots$ & . & .. & . & 21 & 17 & 42 \\
\hline $\begin{array}{l}\text { Site } \\
\text { (Percentage } \\
\text { with } \\
\text { Focal } \\
\text { Tenderness) }\end{array}$ & $\begin{array}{l}\text { Ster } \\
\text { Acro } \\
\text { Scap } \\
\text { Wris } \\
\text { Kne } \\
\text { Hips } \\
\text { Cerv } \\
\text { Dors } \\
\text { Lum }\end{array}$ & $\begin{array}{l}\text { clav } \\
\text { o-cl } \\
\text {-hu } \\
\\
\text { I sp } \\
\text { spin } \\
\text { sp }\end{array}$ & $\begin{array}{l}\text { lar j } \\
\text { cula } \\
\text { ral } j\end{array}$ & & $\begin{array}{l}62 \\
71 \\
67 \\
13 \\
71 \\
62 \\
52 \\
48 \\
33\end{array}$ & $\begin{array}{l}82 \\
82 \\
76 \\
47 \\
76 \\
65 \\
71 \\
41 \\
59\end{array}$ & $\begin{array}{l}69 \\
74 \\
69 \\
40 \\
69 \\
74 \\
67 \\
21 \\
64\end{array}$ \\
\hline
\end{tabular}

also similar (Table VI). In 66 percent. of the patients

TABle VI

INCIDENCE OF SYNOVIAL THICKENING OR EFFUSION IN JOINTS

\begin{tabular}{|c|c|c|c|c|c|c|c|}
\hline Arteritis $\quad$. & $\cdots$ & . & $\cdots$ & $\cdots$ & Definite & Possible & None \\
\hline No. of Patients & $\ldots$ & . & . & . & 21 & 17 & 42 \\
\hline $\begin{array}{l}\text { Joint } \\
\text { (Percentage } \\
\text { with } \\
\text { Synovial } \\
\text { Thickening } \\
\text { or Effusion) }\end{array}$ & \multicolumn{4}{|c|}{$\begin{array}{l}\text { Sterno-clavicular } \\
\text { Acromio-clavicular } \\
\text { Knees } \\
\text { Wrists } \\
\text { Metacarpo-phalangeal } \\
\quad \text { or proximal- } \\
\text { interphalangeal }\end{array}$} & $\begin{array}{r}33 \\
9 \\
57 \\
0 \\
\\
\\
5\end{array}$ & $\begin{array}{l}41 \\
35 \\
47 \\
18 \\
\\
\\
6\end{array}$ & $\begin{array}{l}48 \\
17 \\
50 \\
17 \\
\\
\\
10\end{array}$ \\
\hline
\end{tabular}

with definite arteritis, 76 per cent. of those with possible arteritis, and 70 per cent. of those without arteritis, synovitis was demonstrated in at least one joint. It is possible that this feature would have been found more often in the first group if they had not been treated with suppressive corticosteroid therapy as soon as the diagnosis of arteritis was made. There were also no differences in the degree of synovial thickening or in the frequency or severity of residual instability of the sterno-clavicular joints or of erosive changes on $x$ ray in these or other joints between those with and without arteritis.

The degree of shoulder limitation was also similar in the three groups, contrary to the findings of Gordon, Rennie, and Branwood (1964). The mean angle of shoulder abduction in the three groups was 122,124 , and $128^{\circ}$ respectively.

In the one patient (Appendix Case 80) who had both histologically proven synovitis (Fig. 1) and arteritis (Fig. 5, opposite), the histological appearances in the synovium were indistinguishable from those in the other four patients. No evidence of arteritis was seen in any of the vessels in the synovial biopsies (Dr. J. Ball, 1964).

\section{Large Vessel Involvement}

Large vessel murmurs were present in a significantly higher proportion of the patients with definite arteritis than in those without $(P<0.001)$ (Table VII). Twelve (57 per cent.) with definite

TABLE VII

INCIDENCE OF VASCULAR MURMURS OVER LARGE VESSELS IN PATIENTS AND CONTROL SUBJECTS

\begin{tabular}{|c|c|c|c|c|c|}
\hline Arteritis & .. & Definite & Possible & None & Controls \\
\hline No. of Patients & .. & 21 & 17 & 42 & 80 \\
\hline $\begin{array}{c}\text { Artery } \\
\text { (Percentage } \\
\text { with } \\
\text { Vascular } \\
\text { Murmurs) }\end{array}$ & $\begin{array}{l}\text { Carotid } \\
\text { Subclavian } \\
\text { Axillary } \\
\text { Abdominal } \\
\text { aorta } \\
\text { Femoral }\end{array}$ & $\begin{array}{r}3 \\
10 \\
7 \\
6 \\
6\end{array}$ & $\begin{array}{l}2 \\
5 \\
2 \\
1 \\
4\end{array}$ & $\begin{array}{l}1 \\
3 \\
1 \\
0 \\
1\end{array}$ & $\begin{array}{l}1 \\
6 \\
0 \\
0 \\
0\end{array}$ \\
\hline
\end{tabular}

arteritis, seven (41 per cent.) with possible arteritis, three ( 7 per cent.) without arteritis, and seven ( 9 per cent.) controls had large vessel murmurs. These were more widespread (Table VIII) and usually

NUMBER OF ARTERIES WITH VASCULAR MURMURS IN PATIENTS AND CONTROL SUBJECTS

\begin{tabular}{l|lll|r|r|r|r}
\hline Arteritis &.. &.. &.. & Definite & Possible & None & Controls \\
\hline \multicolumn{1}{l|}{ No. of Patients } &.. &.. & 21 & 17 & 42 & 80 \\
\hline No. of & One & & 2 & 3 & 1 & 6 \\
Large & Two & & 3 & 2 & 1 & 1 \\
Vessels & Three & & 2 & 0 & 1 & 0 \\
with & Four & & 4 & 1 & 0 & 0 \\
Murmurs & Five & & 0 & 0 & 0 & 0 \\
& Six & & 1 & 1 & 0 & 0 \\
\hline
\end{tabular}

louder in the patients with arteritis, and in four with loud murmurs over a subclavian artery a palpable 


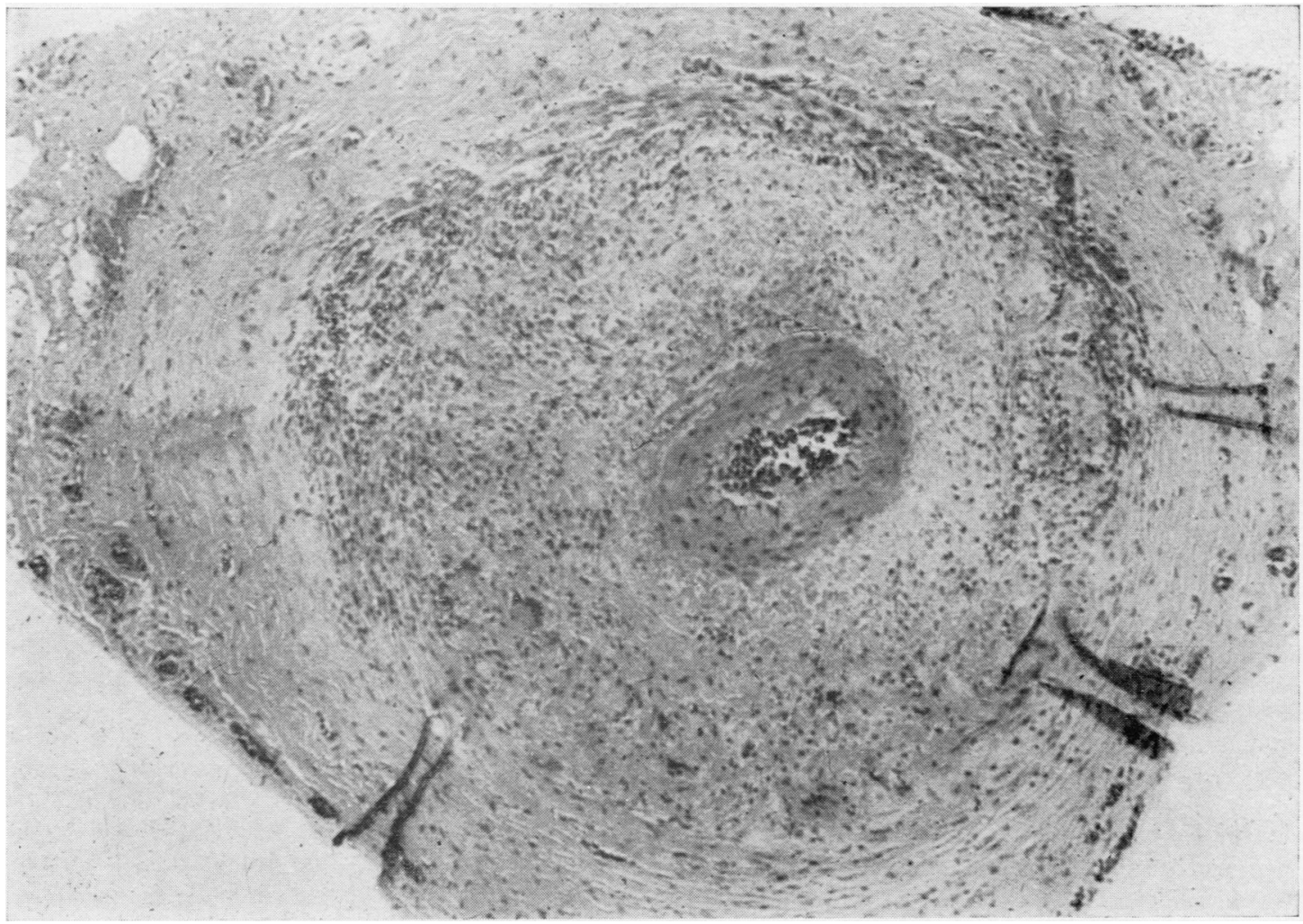

Fig. 5. - Case 80, biopsy of temporal artery, showing typical histologica appearance of giant-cell arteritis. $\times 40$ approx.

thrill was present. In the control subjects, the murmurs over the subclavian artery were all of minimal intensity, and the only subject with murmurs of moderate intensity over the carotid arteries had severe Paget's disease of the skull.

One patient with histologically proven giant-cell arteritis developed complete occlusion of both subclavian arteries (Appendix Case 20), another had occlusion of the left subclavian artery, and four others of whom one had histological temporal arteritis, had partial occlusion of one subclavian artery (Appendix Case 28).

Absent peripheral pulses in the lower limbs were also recorded in a higher proportion of those with arteritis than in those without. In four ( 20 per cent.) with definite arteritis, both the dorsalis pedis and posterior tibial arteries were impalpable, whereas only one $(2.5$ per cent.) without arteritis had complete absence of all these peripheral pulses.

\section{Age at Onset}

The patients with arteritis were as a rule older at the onset of the disease (Table IX), 76 per cent.

TABLE IX

AGE AT ONSET OF DISEASE, BY DEGREE OF ARTERITIS

\begin{tabular}{|c|c|c|c|c|c|}
\hline Arteritis ... & .. & .. & Definite & Possible & None \\
\hline No. of Patients & .. & . & 21 & 17 & 42 \\
\hline \multirow[t]{2}{*}{ Age (yrs) } & $\begin{array}{l}\text { Under } 50 \\
50-59 \\
60-69 \\
70 \text { and Over }\end{array}$ & $\%$ & $\begin{array}{r}5 \\
19 \\
43 \\
33\end{array}$ & $\begin{array}{r}0 \\
41 \\
41 \\
18\end{array}$ & $\begin{array}{r}10 \\
50 \\
33 \\
7\end{array}$ \\
\hline & Mean (yrs) & & 67 & 63 & 58 \\
\hline
\end{tabular}

being aged 60 or more, in contrast with 40 per cent. of those without arteritis. Fourteen cranial artery biopsies in 22 patients over the age of 60 were positive, but only one was positive in the twelve patients below this age.

Although the constitutional symptoms in the patients with and without arteritis were similar, they were usually more severe in those with arteritis. 
Erythrocyte Sedimentation Rate

The ESR tended to be higher in the patients with arteritis (Table $\mathrm{X}$ ); the mean was $79 \mathrm{~mm}$./ hr (Wes-

TABle $X$

HIGHEST RECORDED ERYTHROCYTE SEDIMENTATION RATES (mm./hr.: WESTERGREN)

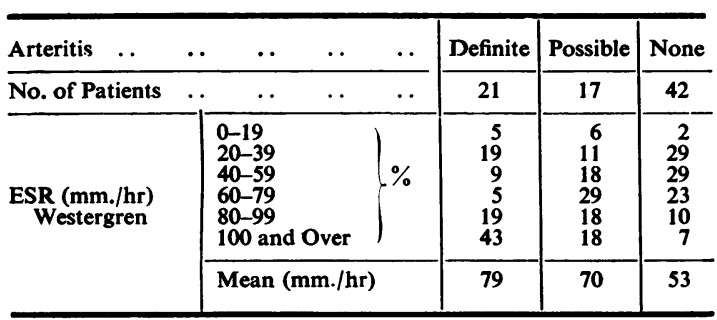

tergren) in those with definite arteritis, $70 \mathrm{~mm}$. in those with possible arteritis, and $53 \mathrm{~mm}$. in those without arteritis. Two patients in the first group had started suppressive corticosteroid therapy when they were first seen and their highest recorded ESRs were 17 and $32 \mathrm{~mm}$. Excluding these two patients, the mean ESR in the first group was $85 \mathrm{~mm}$.; twothirds of those with definite arteritis had an ESR of $80 \mathrm{~mm}$. or more, as compared with one-sixth of those without arteritis.

It must be stressed, however, that in two patients with histologically proven giant-cell arteritis, the highest ESR recorded was $20 \mathrm{~mm}$., and a patient (not included in this series) was recently seen, who had developed sudden blindness of the right eye through partial occlusion of the central retinal artery. There was some return of vision after 30 minutes, after which it remained unchanged. When seen 2 weeks later, her cranial arteries were clinically normal and the ESR $8 \mathrm{~mm}$./ hr (Westergren) but a temporal artery biopsy showed histological changes of arteritis. Treatment with prednisolone was started 3 weeks after the episode of acute visual loss and her vision was restored almost to its previous state.

\section{Discussion}

In this study of eighty patients with polymyalgia rheumatica, no abnormality of muscle was found and it was shown that the pains felt by the patients to be in the muscles, were largely referred from the central joints, tendons, and ligaments.

Palpable synovial thickening of the sternoclavicular joints was the most helpful physical sign, as this was present in $\mathbf{4 0}$ per cent. of these patients at some time during the illness, and was often the only physical sign of the presence of an inflammatory process.
Erosive changes in joints have not been considered to be a radiological feature of polymyalgia rheumatica, but several patients in this study developed radiological joint erosions and some sclerosis of the sacro-iliac joints; the clinical features of these patients were indistinguishable from the rest.

In some patients, synovitis was demonstrated histologically in the sterno-clavicular joints and evidence of arteritis was found in fifteen of the 33 patients who had cranial artery biopsies, the appearances being typical of giant-cell arteritis in nine.

The manifestations in the locomotor system were identical in those with and without evidence of arteritis, and in one patient, both synovitis in the sterno-clavicular joint and giant-cell arteritis in a temporal artery were demonstrated histologically. Rheumatoid factor was not found in the synovial biopsies and the frequency of positive SCAT among these patients was no higher than in the general population (Ball and Lawrence, 1961). It thus seems probable that this arthritis is distinct from rheumatoid arthritis. A possible explanation may be that the synovitis of the central joints and the giant-cell arteritis are manifestations of a single disease process, and it is of interest that in a fatal case of giant-cell arteritis Heptinstall, Porter, and Barkley (1954) found that the head of the femur had been eroded by vascular granulation tissue containing numerous histiocytes and plasma cells.

The potentially serious nature of giant-cell arteritis makes it important to diagnose this disease, which is eminently treatable, before serious complications arise, and to recognize those patients with polymyalgia rheumatica who are likely to develop arteritis. Those developing arteritis are usually more than 60 years old, feel sicker, and have higher sedimentation rates, and more frequent elevations of the alpha $_{2}$ globulins.

An unexpected finding was the frequency with which evidence of arteritis was found on biopsy of a cranial artery which would clinically have been regarded as normal in an elderly patient; moreover arteritis was occasionally found in the presence of a normal ESR.

It is clear that in any patient with this syndrome, or any elderly patient with unexplained pyrexia (Petersdorf and Beeson, 1961; Norris, 1962) or with an unexplained raised ESR, biopsy of a cranial artery should be considered, particularly if there is an accompanying physical or mental deterioration.

\section{Summary}

In this study of polymyalgia rheumatica, no primary abnormality in muscle was found. The 
muscle pains appeared to be largely referred from central joints, tendons, and ligaments.

Giant-cell arteritis was found a high proportion of the patients, and those with and without arteritis had the same manifestations in the locomotor system. Those with arteritis were usually older, had more constitutional illness, higher erythrocyte sedimentation rates, and raised alpha ${ }_{2}$ globulins.

Synovitis of central joints and arteritis may coexist, and it is suggested that they may be manifesta- tions of a single disease process.

I am grateful to Dr. J. Sharp for his assistance, constructive criticism, and the reading of this paper; to Dr. R. Harris for his assistance and advice; to Prof. J. H. Kellgren for permission to report on his patients; to Dr. J. Ball for his detailed study of the synovial biopsies and the synovial micro-photographs; to Dr. F. E. Aaron for the assistance and advice with the histology of the temporal artery biopsies; and to Dr. R. Ollerenshaw for the $x$-ray photographs.

\section{REFERENCES}

Alestig, K., and Barr, J. (1963). Lancet, 1, 1228 (Giant-cell arteritis).

Bagratuni, L. (1953). Ann. rheum. Dis., 12, 98 (A rheumatoid syndrome occurring in the elderly).

- (1956). Lancet, 2, 594 (Anarthritic rheumatoid disease).

- (1957). Ann. rheum. Dis., 16, 104 (Plasma proteins and cryoglobulins in anarthritic rheumatoid disease).

- (1963). Brit. med. J., 1, 513 (Prognosis in the anarthritic rheumatoid syndrome).

Ball, J. (1964). Personal communication.

— and Lawrence, J. S. (1961). Ann. rheum. Dis., 20, 235 (Epidemiology of the sheep cell agglutination test).

Barber, H. S. (1957). I Ibid., 16, 230 (Myalgic syndrome with constitutional effects).

Boyle, A. C., and Beatty, D. C. (1961). Proc. roy. Soc. Med., 54, 681 (Polymyalgia rheumatica).

Bruce, W. (1888). Brit. med. J., 2, 811 (Senile rheumatic gout).

Coomes, E. N., and Sharp, J. (1961). Lancet, 2, 1328 (Polymyalgia rheumatica).

Forestier, J., and Certonciny, A. (1953). Rev. Rhum., 20, 854 (Pseudo-polyarthrite rhizomélique).

Gordon, I. (1960). Quart. J. Med., 29, 473 (Polymyalgia rheumatica).

—, Rennie, A. M., and Branwood, A. W. (1964). Ann. rheum. Dis., 23, 447 (Polymyalgia rheumatica).

Hamrin, B., Jonsson, N., and Landberg, T. (1964). Lancet, 1, 397 (Arteritis in "polymyalgia rheumatica").

Heptinstall, R. H., Porter, K. A., and Barkley, H. (1954). J. Path. Bact., 67, 507 (Giant-cell (temporal) arteritis).

Holst, J. E., and Johansen, E. (1945). Acta med. scand., 122, 258 (A special type of "rheumatic" disease).

Johnston, T. B. (1938). “Gray's Anatomy”, 27th ed., p. 1086. Longmans Green, London.

Kersley, G. D. (1951). " "II Congr. Europ. Reum.”, p. 388. Barcelona (A myalgic syndrome of the aged with systemic reaction).

Kogstad, O. (1963). T. norsk. Laegeforen., 83, 534 (Polymyalgia rheumatica-arteritis temporalis).

Meulengracht, E. (1945). Quoted by Porsman (1951), p. 480.

Norris, T. St. M. (1962). Proc. roy. Soc. Med., 55, 327 (Giant cell arteritis presenting with pyrexia_of uncertain origin).

Olhagen, B. (1963). Acta rheum. scand., 9, 157 (Polymyalgia rheumatica. A form of senile arteritis?).

Petersdorf, R. G., and Beeson, P. B. (1961). Medicine (Baltimore), 40, 1 (Fever of unexplained origin. Report on 100 cases).

Porsman, V. A. (1951). "II Congr. Europ. Reum.", p. 479, Barcelona (Arthritis in old age).

Serre, H., and Simon, L. (1962). Rheumatologie, 14, 1. (De la pseudopolyarthrite rhizomélique ou rhumatisme inflammatoire rhizomélique des gens âgés).

—— (1963). A.I.R., 6, 355. (Polymyalgia rheumatica ou rhumatisme inflammatoire des gens âgés).

Weissenbach, R., Nobillot, A., Freneaux, R., and Coste, F. (1963). Sem. Hôp. Paris, 39, 2073 (Pseudo-polyarthrite rhizomélique). 


\section{APPENDIX \\ Case Histories}

Case 5, a married woman aged 66, gradually developed pain and limitation of movement of the shoulders in October, 1961, followed by pain and swelling of the knees and morning stiffness lasting for several hours.

Examination (October, 1962).- She had no systemic abnormalities apart from a blood pressure of 180/90. There was synovial thickening and tenderness of both sterno-clavicular joints, tenderness of both acromioclavicular joints, and small effusions in both knees. Several interspinous ligaments were tender.

Investigations.-ESR $57 \mathrm{~mm} . / \mathrm{hr}$ (Westergren); haemoglobin 90 per cent. $X$ rays showed no erosive changes in joints, but there was slight forward subluxation of L3 on L4 bertebra. A routine biopsy of the anterior branch of the right temporal artery showed no evidence of arteritis.

Course.-She slowly improved spontaneously and in October, 1963, was clinically in remission, the ESR being $11 \mathrm{~mm}$./ hr (Westergren). In May, 1964, she began to feel ill again and in July, 1964, developed severe bitemporal headaches with scalp tenderness and some weeks later began to have angina pectoris. When she was seen in September, 1964, both temporal arteries were thickened and tender with reduced pulsation. Loud murmurs were now audible over both subclavian arteries.

Investigations (September, 1964).-ESR $110 \mathrm{~mm} . / \mathrm{hr}$ (Westergren); haemoglobin 76 per cent.; serum albumin $3 \cdot 2$ g. per cent., serum globulin $3 \cdot 7$ g. per cent., alpha globulin-marked increase. $X$ rays showed erosions in both sterno-clavicular joints, slight sclerosis and erosion of the left sacro-iliac joint and the public symphysis, and increased forward subluxation of L3 on L4 vertebra. A biopsy of the anterior branch of the left temporal artery showed histological changes of very active giant-cell arteritis.

Treatment.-Suppressive doses of prednisolone resulted in improvement of the temporal headaches, but had no immediate effect on the angina pectoris and vascular murmurs, 6 months later the temporal arteries were clinically normal, but the large vessel murmurs were unchanged. In May, 1966, the angina pectoris was much improved but the large vessel murmurs, although softer, were still present. The ESR was $30 \mathrm{~mm}$./hr in spite of a maintenance dose of $15 \mathrm{mg}$. prednisolone daily.

Comment.-This patient presented with typical polymyalgia rheumatica and synovitis of central joints, $2 \frac{1}{2}$ years later she developed histological giant-cell arteritis, clinical abnormalities of the large vessels, and erosive changes in the joints.
Case 20, a married woman aged 67, awoke one morning in December, 1962, with severe pain and stiffness in the groins and a few days later developed severe pain and $s$ limitation of movement of both shoulders, with prolonged $\overrightarrow{0}$ morning stiffness. This was associated with malaise, loss of appetite, and depression. She lost $22 \mathrm{lb}$. in weight during the next 8 months.

Examination (September, 1963).-Loud murmurs స్ were audible over both subclavian arteries. Both iv shoulder joints were limited in range with shoulder abduction to $110^{\circ}$ on the right and $150^{\circ}$ on the left. $\stackrel{\omega}{\omega}$ There was palpable synovial thickening in the right sternoclavicular joint and both knees had small effusions.

Investigations.-ESR $109 \mathrm{~mm} . / \mathrm{hr}$ (Westergren); serum albumin $3 \cdot 5 \mathrm{~g}$. per cent., serum globulin $4 \cdot 6 \mathrm{~g}$. per cent., alpha 2 and gamma globulin increased.

Course.-She was discharged from hospital after 10 weeks virtually asymptomatic but the ESR was still 93 $\mathrm{mm}$./hr (Westergren); 3 days later she began to feel ill again with dizziness, drowsiness, and pain in the neck and supra-clavicular regions. She had a patchy erythematous rash over the neck and thighs and a pyrexia of $103^{\circ} \mathrm{F}$. There was clinical evidence of occlusion of both subclavian arteries and a moderately loud murmur was audible over the abdominal aorta. The cranial arteries were clinically normal. A biopsy of the left superficial temporal artery showed histological changes of giant-cell arteritis.

Treatment.-Prednisolone $15 \mathrm{mg}$. daily resulted in rapid symptomatic improvement, 6 weeks later the radial pulses were weakly palpable, and 18 months later while $\delta$ still taking $10 \mathrm{mg}$. of prednisolone daily, she had no evidence of disease activity and the radial pulses were $O$ easily palpable, but loud murmurs were still audible over both subclavian arteries.

Comment.-This patient with polymyalgia rheumatica $\stackrel{N}{\sigma}$ had central synovitis and developed an aortic arch syn- $N$ drome which responded to prednisolone. She also had 오 histological evidence of giant-cell arteritis in a temporal $\omega$ artery biopsy.

Case 25, a man aged 64, was well until March, 1963, when he developed bilateral hip girdle pain, followed a week $\stackrel{\mathscr{?}}{+}$ later by pain in the neck, back, both shoulder girdles, $\square$ and the right knee, with morning stiffness persisting for $\overline{\mathrm{O}}$ 3 hours. These symptoms became worse for 2 months, $\overparen{D}$ when he began to feel ill, tired, and lacking in energy, and $\frac{\mathbb{D}}{\mathrm{D}}$ lost $7 \mathrm{lb}$. in weight over a few months. 
Examination (September, 1963).-There were no systemic abnormalities. Spinal movement was moderately limited and there was tenderness over the L5-S1 interspinous ligament. There was synovial thickening and tenderness of the left sterno-clavicular joint. Both shoulder girdles were limited, with total abduction on the right to $160^{\circ}$ and on the left to $150^{\circ}$. There were tender focal areas around the pelvis and under both heels.

Investigations.-ESR $40 \mathrm{~mm} . / \mathrm{hr}$ (Westergren); SCAT negative.

Course.-Within a few months he began to improve spontaneously and, when seen in October, 1964, was in complete clinical remission. The ESR was then $20 \mathrm{~mm}$./ hr (Westergren).

Comment.-The clinical picture was typical of those patients who presented with uncomplicated polymyalgia rheumatica.

Case 28, a married woman aged 55, rapidly developed pain and limitation of both hips, knees, and the lumbar spine in September, 1963. After 2 weeks her neck became painful and both shoulders were limited and painful. Morning stiffness persisted for 4 hours.

Examination (October, 1963).- The blood pressure was $130 / 70$ in each arm with no vascular abnormalities. The whole spine was limited and painful on movement and multiple interspinous ligaments were tender. Both shoulder girdles were limited with total abduction to $70^{\circ}$ on each side. There was synovial thickening and tenderness of both sterno-clavicular joints, both knees had synovial effusions, and there were multiple focal tender areas on the bony points of the pelvis.

Investigations.-ESR $60 \mathrm{~mm}$./ hr (Westergren); haemoglobin 76 per cent.; serum albumin $3 \cdot 2$ g. per cent., serum globulin $3.9 \mathrm{~g}$. per cent. A routine biopsy of the right temporal artery showed no histological abnormality.

Course.-After 9 weeks she slowly began to improve and by February, 1964, was much improved, although the shoulder girdles were still slightly limited in range and the ESR was $25 \mathrm{~mm}$./ hr (Westergren).

2 months later the joint symptoms had subsided and the patient felt very well, although the ESR was $100 \mathrm{~mm} . / \mathrm{hr}$ (Westergren). $X$ rays showed a large erosion of the medial aspect of the right clavicle (Fig. 4).

3 months later she had lost $9 \mathrm{lb}$. in weight and tired rapidly. It was noted that she had developed a loud murmur over the right subclavian artery and an even louder murmur accompanied by a palpable thrill over the left subclavian artery, which was tortuous and had reduced pulsation. The blood pressures were $150 / 80$ in the right arm and 120/80 in the left arm.

Treatment.-Prednisolone administration was followed by a general improvement and the ESR rapidly returned to normal, but the murmurs over the arteries have persisted.
Comment.-This patient presented with typical polymyalgia rheumatica and subsequently developed an erosion of the right sterno-clavicular joint and clinical abnormalities of the large vessels.

Case 69, a man aged 76, had always enjoyed good health and had worked as an accountant and played chess for his county until a few months before the onset of his illness. In March, 1963, he noticed that his temporal arteries had become very prominent and slightly tender. A month later he developed bilateral shoulder and hip girdle pain and soon after that his memory and intellect began to deteriorate rapidly. In September, 1963, both knees and the lumbar region became painful and he began to feel excessively tired and lacking in energy.

Examination (April, 1964).-He looked ill and had marked intellectual impairment. The blood pressure was $130 / 70$ in each arm. Both temporal and facial arteries were thickened with absent pulsation, but not tender. Both shoulders had an almost full range of movement with painful arcs on abduction. The left acromio-clavicular joint was tender and the left sternoclavicular joint unstable. Multiple focal tender areas were present around the knees and the pelvis.

Investigations.-ESR $85 \mathrm{~mm}$./hr (Westergren); haemoglobin 74 per cent.; SCAT negative; serum albumin $3 \cdot 7$ g. per cent., serum globulin 3.4 g. per cent.; alpha globulin increased. A biopsy of the left temporal artery showed histological changes of active giant-cell arteritis, with complete occlusion of the lumen by intimal prolipheration.

Treatment.-Prednisolone $20 \mathrm{mg}$. daily caused a rapid improvement in his general health and locomotor symptoms, and the ESR dropped to $20 \mathrm{~mm}$./ hr within one week. The thickening of the temporal arteries slowly subsided, but the pulsation did not return. The prednisolone was reduced to $15 \mathrm{mg}$. daily after 3 weeks, and 6 months later to $10 \mathrm{mg}$. daily. On this dose he remained unchanged and the ESR remained at about $10 \mathrm{~mm}$./ hr (Westergren).

There was no improvement in his intellectual state, and a repeat biopsy of the right artery in January, 1965, still showed the changes of an active giant-cell arteritis.

Comment.-This patient had obvious temporal arteritis, but had never complained of headaches; 22 months after the onset of the temporal arteritis and after 9 months of suppressive corticosteroid therapy, he still showed the histological changes of active giant-cell arteritis in a temporal artery biopsy.

Case 80, an unmarried woman aged 81, had always enjoyed excellent health until September, 1962, when following the death of her sister, both knees became painful and swollen and she began to feel ill, tired, lacking in energy, and depressed. Her condition remained unchanged until January, 1964, when both shoulders became painful and limited with morning stiffness lasting for one hour. In August, 1964, he neck became painful and she also 
developed slight pain which was present for only a few minutes in the mornings, in the region of the temporomandibular joints. She had never suffered from severe headaches.

Examination (September, 1964)._-An area half an inch long of the anterior branch of the left superficial temporal artery was slightly thickened and tender. There was marked synovial thickening and instability of both sterno-clavicular joints and slight limitation of shoulder girdle range of movement. The left knee had a moderate effusion.

Investigations.-ESR $20 \mathrm{~mm}$./hr (Westergren); haemoglobin 98 per cent.; white cell count $8,800 /$ c.mm.; SCAT negative; serum albumin $4 \cdot 5$ g. per cent., serum globulin $3 \mathrm{~g}$. per cent.; electrophoresis normal. A biopsy of the left sterno-clavicular joint showed histological changes of active synovitis (Fig. 1). A biopsy of the left superficial temporal artery at the site of the thickening showed histological changes of active giant-cell arteritis (Fig. 5).

Comment.-This patient had coincidental histological changes of giant-cell arteritis in a temporal artery, and synovitis in a central joint.

Les manifestations articulaires et vasculaires de la pseudopolyarthrite rhizomélique

RÉSUMÉ

Dans cette étude portant sur la pseudo-polyarthrite rhizomélique on n'y trouva aucune lésion primitive au niveau du muscle. Les douleurs ressenties au niveau des muscles semblèrent être en grande partie diffusées à partir des centres articulaires, des tendons et des ligaments.

On trouva des lésions d'artérite giganto-cellulaire chez une forte proportion des malades, et les manifestations observées au niveau de l'appareil locomoteur furent les mêmes chez les sujets présentant des lésions d'artérite et chez les autres. Les porteurs d'artérite étaient habituellement plus âges que les autres, plus sévèrement malades et accusaient une vitesse de sédimentation globulaire plus élevée et un taux des alpha 2 globulines plus haut.

La synovite des articulations centrales et l'artérite coëxistent et l'on suggère qu'il s'agit ici de manifestations d'un seul processus morbide.

Las manifestaciones articulares y vasculares de la polimialgia reumàtica

SUMARIO

En este estudio de la polimialgia reumática no se encontró lesión primaria en el músculo. Los dolores musculares eran referidos, en su mayor parte, desde articulaciones centrales, tendones y ligamentos.

Encontráronse lesiones de arteritis giganto-celular en una proporción elevada de enfermos, y las manifestaciones en el sistema locomotor fueron las mismas en los sujetos con o sin lesiones de arteritis. Los sujetos con arteritis fueron generalmente más viejos que los demás, padecían otras enfermedades constitucionales y acusaban una velocidad de sedimentación globular más elevada y cifras de globulinas alfa $a_{2}$ aumentadas.

La sinovitis de las articulaciones centrales y la arteritis coexistían y se sugiere que se trata aquí de manifestaciones de un solo proceso morboso. 